\title{
Bottom sediments as a potential source of phosphorus in the riverine-lacustrine system of the Kośna River (Northeastern Poland)
}

\author{
Izabela Bigaj, Michał Łopata, Julita Dunalska, Daniel Szymański, Rafał Zieliński
}

Department of Environment Protection Engineering, University of Warmia and Mazury, Prawocheńskiego 1, 10-950 Olsztyn, Poland, e-mail: izabela.piorkowska@uwm.edu.pl

\begin{abstract}
Sediments from hypereutrophic Lake Łajskie localized in northeastern Poland were examined on the basis of P-fraction. The sediments were collected at five sampling sites. In the investigated lake, the rank order of $\mathrm{P}$-fractions was $\mathrm{HCl}-\mathrm{P}>\mathrm{BD}-\mathrm{P}>\mathrm{NH}{ }_{4} \mathrm{Cl}-\mathrm{P}>$ $\mathrm{NaOH}-\mathrm{nrP}$. The loosely sorbed phosphorus $\mathrm{NH}_{4} \mathrm{Cl}-\mathrm{P}$ represented $<3 \%$ of the sedimentary inorganic phosphorus, while the reductant phosphorus (BD-P) ranged from 2 to $10 \%$. The calcium bound phosphorus ( $\mathrm{HCl}-\mathrm{P}$ ) showed considerable contribution (59-74\%) to the sedimentary inorganic P-loads. BDP was the most reactive fraction in Lake Łajskie. Iron compounds and organic matter seem to play a significant role in regulating this labile P-budget.
\end{abstract}

Key words: bottom sediments, organic matter, nitrogen, phosphorus, riverine-lacustrine systems

\section{Introduction}

Phosphorus has been recognized as the most critical nutrient limiting lake productivity. External and nonpoint sources such as rainfall, runoff, soil leaching, industrial and municipal effluents are the main sources of phosphorus in lakes. Moreover, there are also internal sources from the system itself, such as aquatic plants, algae and sediments. The trophic status of the lakes is usually dependent on the P-concentration in the water. In addition, the trophic status and the trophic development of the system are also influenced by the phosphorus content in lake sediments. Usually lake sediments act as a sink of phosphorus. However, under certain environmental conditions, the sediments may become a possible phosphorus source that will support the trophic status of the lake even after a reduction of external loading (Ramm and Scheps 1997; Zhou et al. 2001; Kaiserli et al. 2002).

The phosphorus content in sediments depends on the sediment composition, the sedimentation rate, the physicochemical conditions and the extent of diagenetic processes (Gonsiorczyk et al. 1998). Total concentrations of phosphorus in sediments cannot predict the potential ecological danger. The fraction of available phosphorus is an important parameter for predicting future internal P-loading (Kalff 2002). In the surface layer (ca. $10 \mathrm{~cm}$ ) of sediment is located approximately $90 \%$ of the phosphorus which occurs in the whole ecosystem (Wetzel 2001; Kalff 2002).

The factors regulating $\mathrm{P}$ release from sediments are redox reactions, adsorption, mineral phase solubility and mineralization of organic matter, but the major controlling parameters are dissolved oxygen, nitrates, sulphates, $\mathrm{pH}$, temperature and salinity (Kleeberg and Dudel 1997; House and Denison 2000; Thirunavukkarasu et al. 2000, Søndergaard et al. 2003). The longterm behaviour of sediment bound $\mathrm{P}$ in influencing eutrophication of water can be more efficiently defined on the basis of P-fractions, instead of total phosphorus content. Murphy et al. (1999) determined that in eutrophic lakes, phosphorus released from sediments may provide up to $99 \%$ of the total content of this element in the lake.

The fractions are $\mathrm{P}$-forms binding to metals and to organic matter, measured by different sequential extraction schemes, so-called P-fractionations. P-fractionations of sedimentary-P are divided into different 
fractions such as labile $\mathrm{P}$, reductant $\mathrm{P}$, metal bound $\mathrm{P}$, occluded $\mathrm{P}$ and organic $\mathrm{P}$ by using various chemical extractants (Chang and Jackson 1957; Williams et al. 1976; Golachowska 1977a, b, c; Psenner 1988; Van Hullebush et. al. 2003). Moreover, in view of the potential P-bioavailability, the extracted fractions may be characterized as water-soluble $\mathrm{P}$, readily resorbable $\mathrm{P}$, algal available $\mathrm{P}$ or ecologically important $\mathrm{P}$ (Pettersson 2001; Zhou et al. 2001; Kaiserli et al. 2002).

The aim of this study was to investigate the different P-forms present in the sediments of a lake located in northeastern Poland in the riverine system of Kośna - hypertrophic Lake Łajskie - and to evaluate their possible contribution to the P-loadings. For this purpose, a sequential extraction scheme was employed providing four P-fractions: loosely sorbed $\mathrm{P}$, metal oxide bound $\mathrm{P}$, reductant soluble $\mathrm{P}$ and calcium bound $\mathrm{P}$.

\section{Study sites}

The studied Lake Łajskie is located in northeastern Poland, about $30 \mathrm{~km}$ SW of Olsztyn (Fig. 1). A small part of the area is protected by a reservation, but most of the catchment consists of forest, wasteland and buildings. The major sources that affect the water quality and the trophic status of lakes are agricultural runoff, animal husbandry effluents, and untreated or semi-treated domestic effluents. Other important sources are resuspended stream sediments and eroded bank materials. The morphometric data of the studied

Table 1. Selected morphometric characteristics of the lake under study (modified WIOŚ 1998)

\begin{tabular}{lcc}
\hline \multicolumn{1}{c}{ Parameter } & Unit & Value \\
\hline Water surface area & {$[\mathrm{ha}]$} & 53.5 \\
Volume & {$\left[\mathrm{dam}^{3}\right]$} & 2106.5 \\
Maximum depth & {$[\mathrm{m}]$} & 7.6 \\
Mean depth & {$[\mathrm{m}]$} & 3.9 \\
Relative depth & & 0.0104 \\
Maximum length & {$[\mathrm{m}]$} & 1050 \\
Maximum width & {$[\mathrm{m}]$} & 800 \\
Length of shoreline & {$[\mathrm{m}]$} & 3300 \\
Development of shoreline & & 1.27 \\
Total catchment area & {$\left[\mathrm{km}^{2}\right]$} & 57 \\
Direct catchment area & {$\left[\mathrm{km}^{2}\right]$} & 0.57 \\
Woodland area & {$\left[\mathrm{km}^{2}\right]$} & 48.45 \\
Wasteland area & {$\left[\mathrm{km}^{2}\right]$} & 3.99 \\
Building area & {$\left[\mathrm{km}^{2}\right]$} & 3.42 \\
Farmland area & {$\left[\mathrm{km}^{2}\right]$} & 1.14 \\
\hline
\end{tabular}

lake are shown in Table 1. Lake Łajskie is an ellipticshaped lake with a surface area of 53.5 ha and a mean depth of $3.9 \mathrm{~m}$. The maximum depth $8.4 \mathrm{~m}$ is observed in the central part. Small streams transport significant quantities of particulate matter in the W-SW part of the lake. At the beginning of summer, during water stratification anoxic conditions are observed in the bottom, mainly in the deepest part of the lake. The water quality has deteriorated and the lake has been classified as hypertrophic (IOŚ 2009). The nutrient enrichment of the lake has seriously degraded the aquatic ecosystem and led to diverse problems such as toxic algal blooms, low water transparency, severe depletion of dissolved oxygen, fish kills, loss of biodiversity, etc.

\section{Methods}

Phosphorus fractionation. Surficial sediment samples were collected once in July 2009, from five sampling sites of Lake Łajskie. Sediment samples (0-5 $\mathrm{cm}$ layer, 6-10 cm layer) were collected using a Kajak sampling device. Before the analysis, the samples were dried and homogenized in a porcelain mortar. The sequential extraction scheme of Psenner et al. (1984) with slight modifications by Van Hullebush et al. (2003) was used for P-fractionation of lake sediments. Sediment fractions were subjected to sequential chemical extraction with $1 \mathrm{M} \mathrm{NH}_{4} \mathrm{Cl}, 0.11 \mathrm{M} \mathrm{NaH}$ $\mathrm{CO}_{3}, \mathrm{Na}_{2} \mathrm{~S}_{2} \mathrm{O}_{4}, 1 \mathrm{M} \mathrm{NaOH}$ and $0.5 \mathrm{M} \mathrm{HCl}$. The extracts were centrifuged and the supernatants were filtered through a $0.45 \mu \mathrm{m}$ phosphorus-free membrane. The soluble reactive phosphorus in each fraction was determined by the molybdenum blue method (APHA 1985). This extraction procedure fractionates sedimentary phosphorus into loosely sorbed $\mathrm{P}\left(\mathrm{NH}_{4} \mathrm{Cl}-\right.$ $\mathrm{P})$, reductant soluble $\mathrm{P}(\mathrm{BD}-\mathrm{P})$, metal oxide bound $\mathrm{P}$ $(\mathrm{NaOH}-\mathrm{P})$ and calcium bound $\mathrm{P}(\mathrm{HCl}-\mathrm{P})$.

Sedimentary water characteristic. The bottom sediment samples were collected in 2009 by a Kajak sampling device in the deepest part of the lake (position 1) (Fig. 2) five times from April to October. Supernatant water was obtained by decantation of the $10 \mathrm{~cm}$ layer of water directly above the sediment. The surface layer of sediments $(10 \mathrm{~cm})$ was analysed. Sediment cores were divided into 2 layers: $5 \mathrm{~cm}$ each $(0-5$ $\mathrm{cm}, 6-10 \mathrm{~cm}$ ). Interstitial water was separated by centrifugation of sediments $(3000 \mathrm{rpm}, \mathrm{t}=20 \mathrm{~min})$. In sedimentary water, the content of nitrogen and phosphorus, iron and manganese was determined by using the protocol proposed by Hermanowicz et al. (1999). 


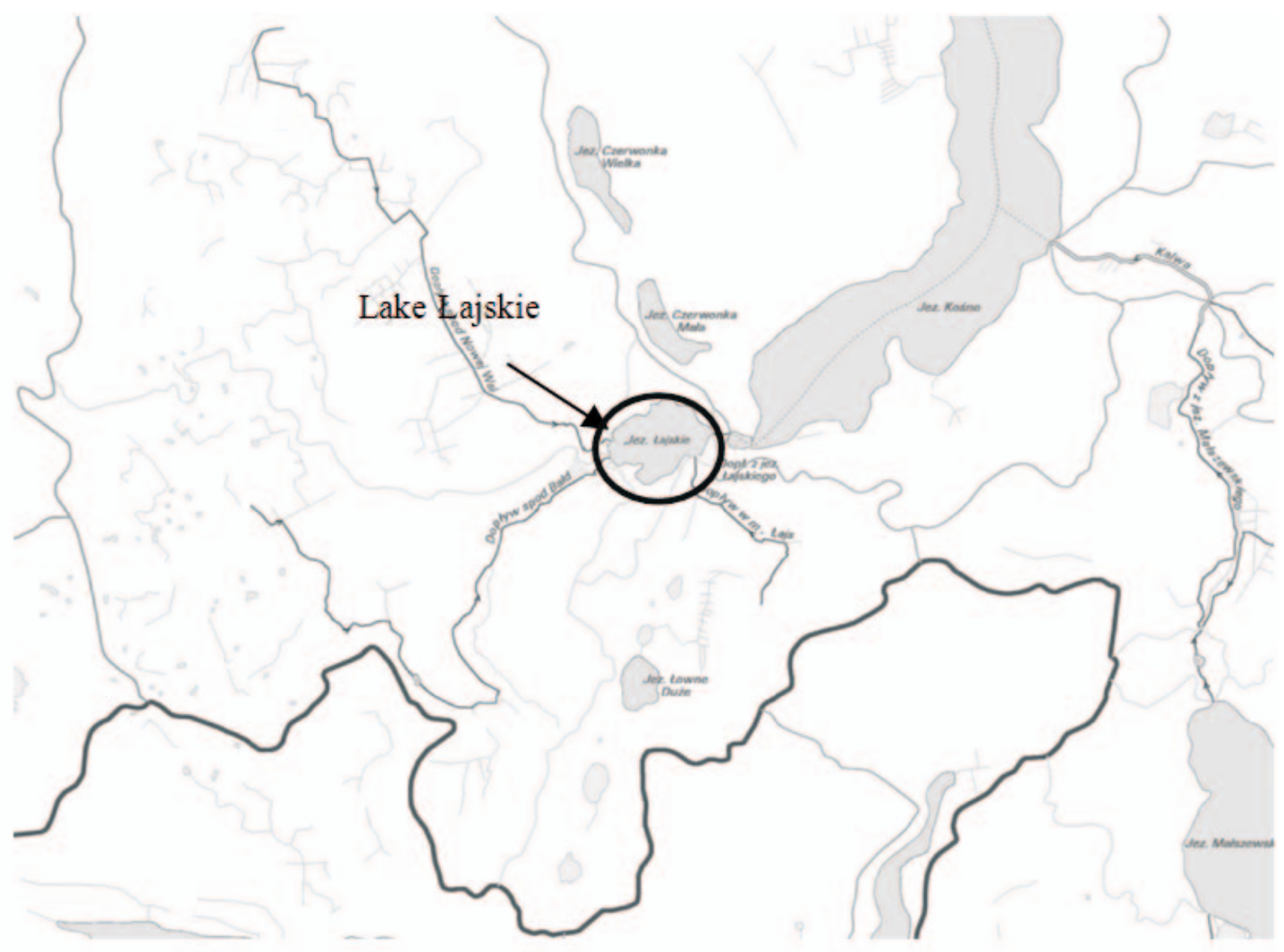

Fig. 1. Location of Lake Łajskie

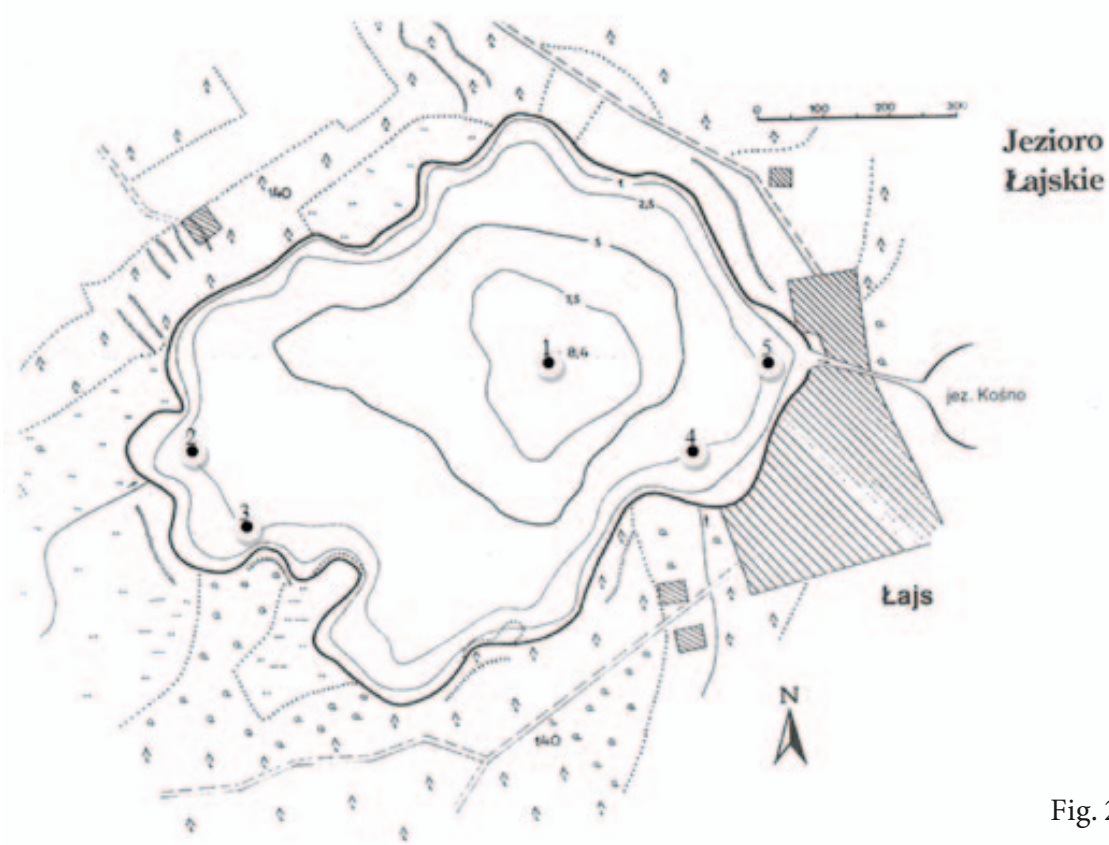

Fig. 2. The study sites 


\section{Results}

Nutrient concentrations. Total nitrogen followed a similar pattern to $\mathrm{NH}_{4}-\mathrm{N}$, which contributed an average of $84 \%$ of TN between June and September, but only $45 \%$ across the mixing periods. Total nitrogen concentrations reached a maximum of $18.76 \mathrm{mg} \mathrm{dm}^{-3}$ in supernatant in June, $37.24 \mathrm{mg} \mathrm{dm}^{-3}$ (in July) and $56.56 \mathrm{mg} \mathrm{dm}^{-3}$ (in June) in interstitial water, $0-5 \mathrm{~cm}$ and 6-10 $\mathrm{cm}$ layer, respectively (Figs $3,5,7)$. Concentrations of $\mathrm{NH}_{4}-\mathrm{N}$ were reasonably uniform averag- ing $1.64 \mathrm{mg} \mathrm{dm}^{-3}$ (Figs 5, 7), then increased steadily to a maximum of $14.00 \mathrm{mg} \mathrm{dm}^{-3}$, before declining to $1.2 \mathrm{mg} \mathrm{dm}^{-3}$, when the water column was once again mixed. Concentrations of $\mathrm{NH}_{4}-\mathrm{N}$ were high in interstitial water (Fig. 7), reaching a maximum of $30.63 \mathrm{mg}$ $\mathrm{dm}^{-3}$ and $50.96 \mathrm{mg} \mathrm{dm}^{-3}$ during the stratification, and declined towards the end of the stratified period.

Total phosphorus concentrations show a similar pattern to those mineral forms (Figs 4, 6, 8). Mineral phosphorus contributed up to $55 \%$ of the TP. The maximum concentration of TP was in summer

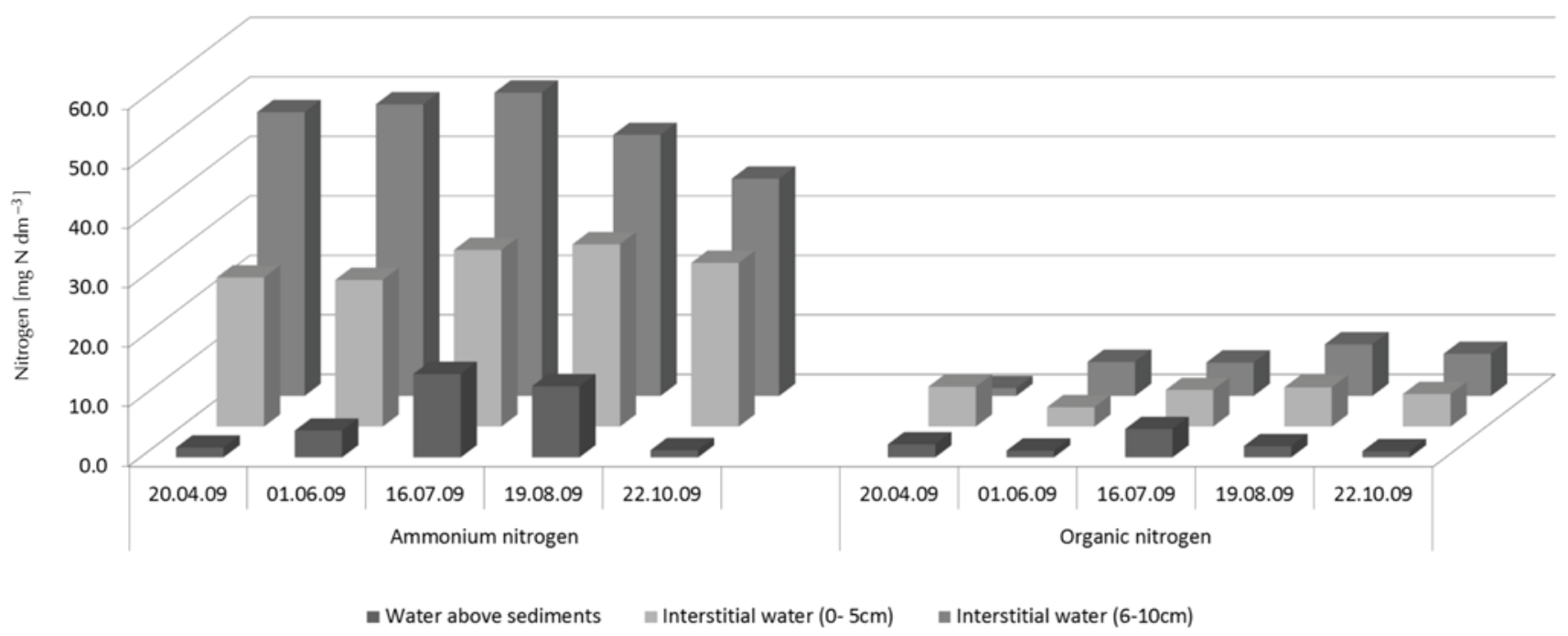

Fig. 3. Seasonal variability of nitrogen compounds

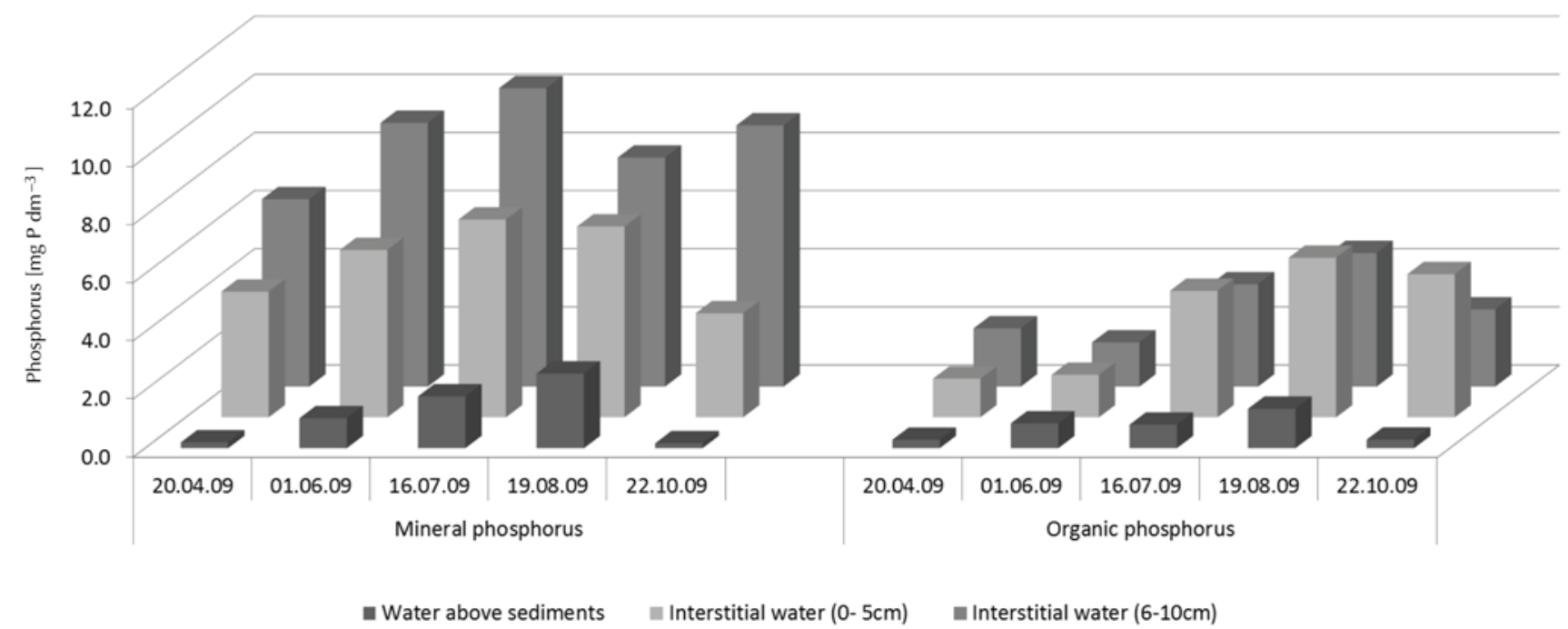

Fig. 4. Seasonal variability of phosphorus compounds 


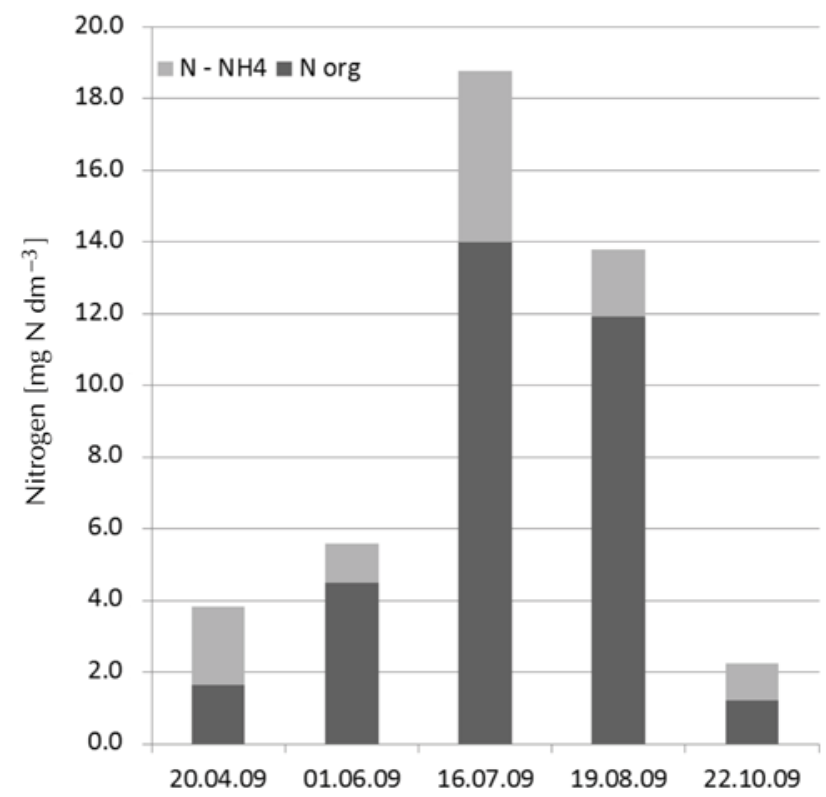

Fig. 5. Seasonal variability of nitrogen compounds in supernatant

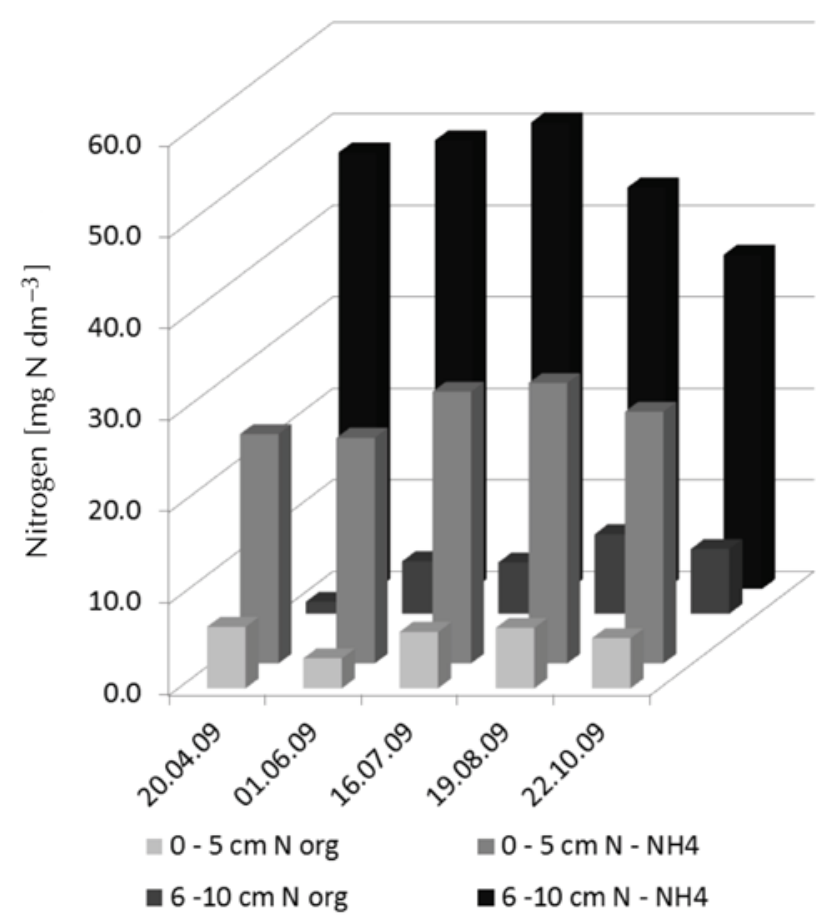

Fig. 7. Seasonal variability of nitrogen concentration in interstitial water

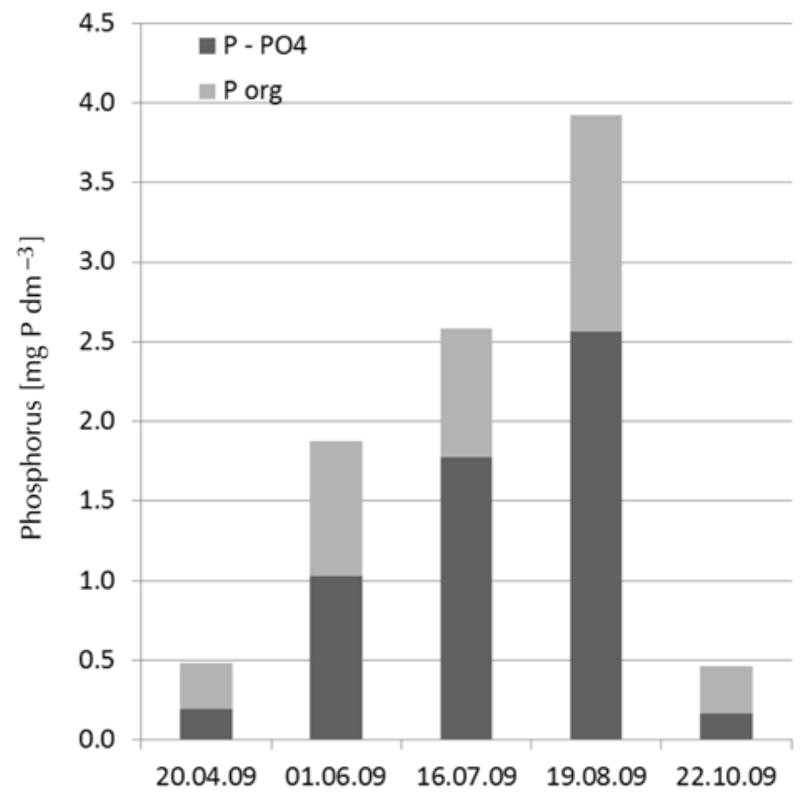

Fig. 6. Seasonal variability of phosphorus compounds in supernatant

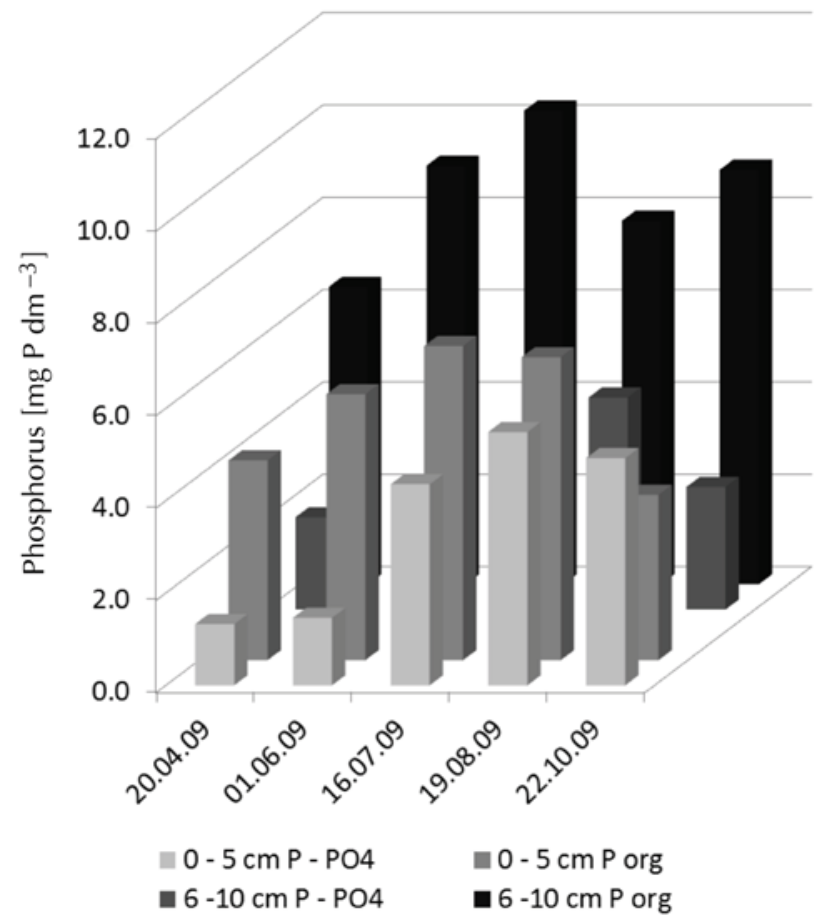

Fig. 8. Seasonal variability of phosphorus concentrations in interstitial water 
(3.92 $\mathrm{mg} \mathrm{P} \mathrm{dm}^{-3}$ - supernatant, $12.05 \mathrm{mg} \mathrm{P} \mathrm{dm}^{-3}$ and $13.78 \mathrm{mg} \mathrm{P} \mathrm{dm}^{-3}$ in interstitial water, $0-5 \mathrm{~cm}$ and $6-10$ $\mathrm{cm}$ layer respectively). Concentrations of phosphorus were relatively uniform during the mixing periods (spring and autumn) at around $0.47 \mathrm{mg} \mathrm{dm}^{-3}$ in supernatant, $7.08 \mathrm{mg} \mathrm{dm}^{-3}(0-5 \mathrm{~cm})$ and $10.04 \mathrm{mg} \mathrm{dm}^{-3}(6-$ $10 \mathrm{~cm}$ ) in interstitial water. In these terms, the values of $\mathrm{P}$ were determined by organic form, respectively: $60 \%$ of TP - spring; $64 \%$ of TP - autumn.

Mass ratios of TN:TP in the sedimentary water (above sediments and interstitial water) were higher at the onset of circulation $7: 1$, then declined to an average ratio of 3:1 during the stratified period (Figs 3, 4).

Manganese and iron. A similar diversity was found for iron and manganese. Iron concentrations reached a maximum of $1.64 \mathrm{mg} \mathrm{dm}^{-3}$ in July in supernatant, $11.50 \mathrm{mg} \mathrm{dm}^{-3}$ (October) and $11.20 \mathrm{mg} \mathrm{dm}^{-3}$ (June) in $0-5 \mathrm{~cm}$ and $6-10 \mathrm{~cm}$ interstitial water, respectively (Fig. 9), and declined during the circulation period.

The maximum concentration of manganese was in summer (1.65 $\mathrm{mg} \mathrm{Mn} \mathrm{dm}^{-3}$ - supernantant, $2.06 \mathrm{mg}$ $\mathrm{Mn} \mathrm{dm}^{-3}$ and $2.96 \mathrm{mg} \mathrm{Mn} \mathrm{dm}^{-3}$ in interstitial water, 0-5 $\mathrm{cm}$ and 6-10 $\mathrm{cm}$ layer respectively). Concentrations of manganese were relatively uniform during the mixing periods at around $0.20 \mathrm{mg} \mathrm{dm}{ }^{-3}$ in supernatant, 1.42 $\mathrm{mg} \mathrm{dm} \mathrm{m}^{-3}(0-5 \mathrm{~cm})$ and $0.82 \mathrm{mg} \mathrm{dm}^{-3}(6-10 \mathrm{~cm})$ in interstitial water.

Fractions of phosphorus. The mean $\mathrm{NH}_{4} \mathrm{Cl}-\mathrm{P}$ concentrations in total sediment were low: $0.01 \mathrm{mg} \mathrm{P}$ $(\mathrm{g} \mathrm{DW})^{-1}$ in the profundal zone (site 1); $0.05 \mathrm{mg} \mathrm{P}$ (g $\mathrm{DW})^{-1}$ at site 3 (inflow zone - Bałdy) (Fig. 11). The loosely sorbed $\mathrm{P}$ represents $<3 \%$ of the sedimentary inorganic $\mathrm{P}$ in the lake system (Fig. 11).

The BD-P concentrations in both lakes exhibited high variability. BD-P concentrations were almost twice as high as loosely sorbed P. The relative contribution of $\mathrm{BD}-\mathrm{P}$ to the sedimentary inorganic $\mathrm{P}$ was from $1.9 \%$ in the inflow zone from Łajs (site 4) to $9.1 \%$ in outflows (site 5) (Fig. 11).

The mean $\mathrm{NaOH}-\mathrm{P}$ concentrations in total sediment were from $0.01 \mathrm{mg} \mathrm{P}(\mathrm{g} \mathrm{DW})^{-1}$ (in the outflow site 5) to $0.14 \mathrm{mg} \mathrm{P}(\mathrm{g} \mathrm{DW})^{-1}$ (in the profundal zone site 1) (Fig. 11). The relative contribution of $\mathrm{NaOH}-\mathrm{P}$ to sedimentary inorganic $\mathrm{P}$ was rather similar in other sites (ca. $0.8 \%$ ).

Most of the sedimentary inorganic $\mathrm{P}$ in all of the sampling sites was in $\mathrm{HCl}$ - soluble forms (from $0.55 \mathrm{mg} \mathrm{P}(\mathrm{g} \mathrm{DW})^{-1}$ in the outflow to $2.81 \mathrm{mg} \mathrm{P}$ (g $\mathrm{DW})^{-1}$ in the profundal zone) (Fig. 11). This fraction was dominated by sedimentary P-load ranging from $59 \%$ to $74 \%$ (Fig. 11 ).

\section{Discussion}

The results of this study show that during summer stratification the hypolimnetic sediments within a lake can act as a source for both phosphate and ammonium to the water column. Rates of sediment nutrient release in Lake Łajskie are comparable to studies from other hypereutrophic lakes (Penn et al. 2000; Brzozowska 2003; Brzozowska and Kang 2010; Kentzer 2001). Increased values of iron and manganese in the water might be relevant to the release procedure. The noted levels of iron were several times higher than those observed during the restoration of Lake Długie (Brzozowska 2003). Iron and manganese are very sensitive elements to changes in oxidationreduction potential in the interphase and are therefore quite easily exported from the bottom to water oxygenation. The release may occur not only as a result of abiotic reactions, but also by microbiological activity (Brzozowska 2003; Søndergaard et al. 2001). A quite high content of nutrients, iron and manganese was found in supernatant during hypolimnion water deoxidation. This evidence suggested that the internal loading processes take place in Lake Łajskie.

The determinant element in most cases of the trophic state of the reservoir is phosphorus. Generally, phosphorus bound to various components such as metal oxides, organic matter or calcium carbonate was deposited (Brzozowska and Kang 2010; Kentzer 2001; Van Hullebush 2003).

$\mathrm{NH}_{4} \mathrm{Cl}-\mathrm{P}$ represents loosely sorbed $\mathrm{P}$. This fraction may contain porewater $\mathrm{P}, \mathrm{P}$ released from $\mathrm{CaCO}_{3}-$ associated phosphorus or leached $\mathrm{P}$ from decaying cells of bacterial biomass in deposited phytodetrital aggregates (Gonsiorczyk et al. 1998; Pettersson 2001). $\mathrm{NH}_{4} \mathrm{Cl}-\mathrm{P}$ is a seasonally variable pool of phosphorus compounds dissolved in the interstitial water (Rydin 2000). The loosely sorbed $P$ represents $<1 \%$ of the sedimentary inorganic $\mathrm{P}$ in the investigated lake system. Values ranging from $1 \%$ to $25 \%$ have been reported for calcareous lakes with the upper values being attributed to a high degree of oversaturation (Penn et al. 1995).

$\mathrm{BD}-\mathrm{P}$ represents the redox-sensitive $\mathrm{P}$ forms, mainly bound to Fe-hydroxides and Mn compounds (Kozerski and Kleeberg 1998). This fraction is considered to be a potentially mobile pool of $\mathrm{P}$ and is algal 


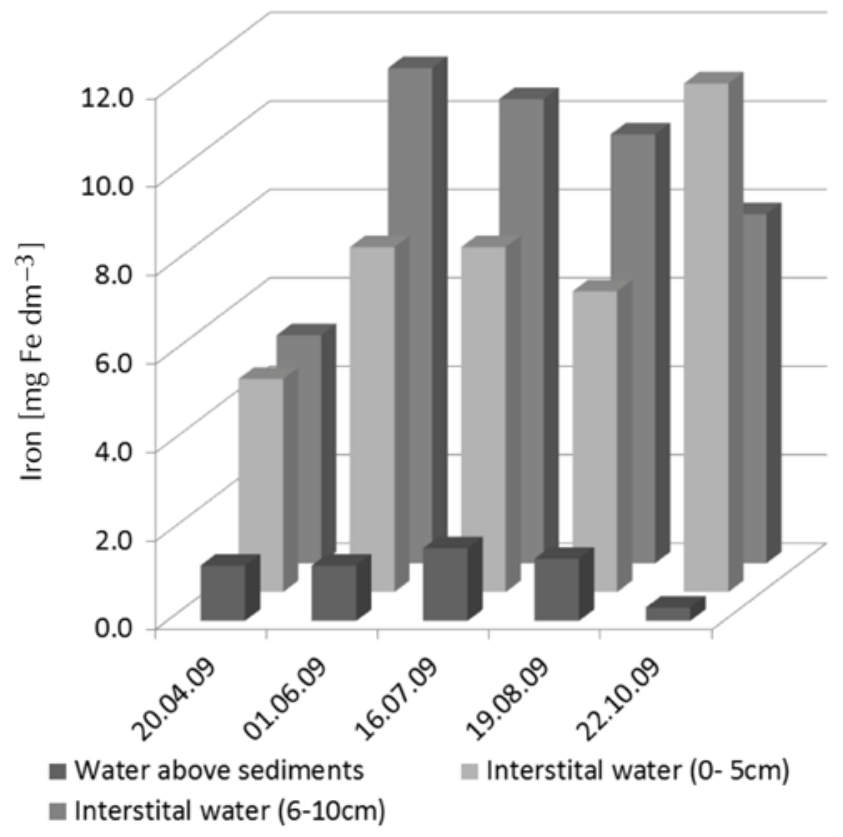

Fig. 9. Seasonal variability of iron concentrations

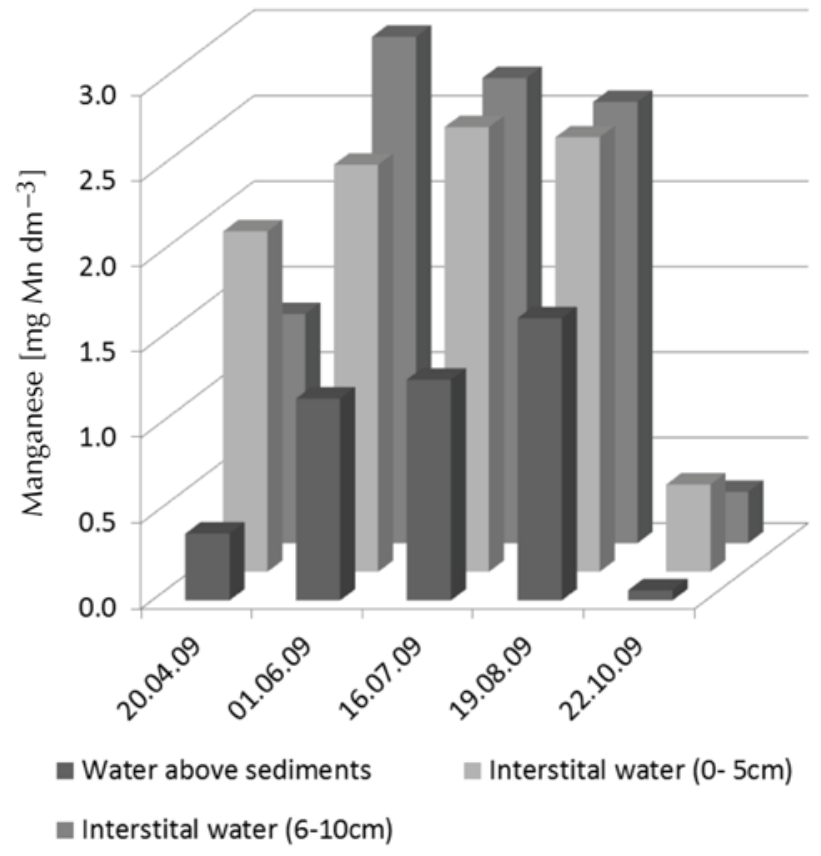

Fig. 10. Seasonal variability of manganese concentrations

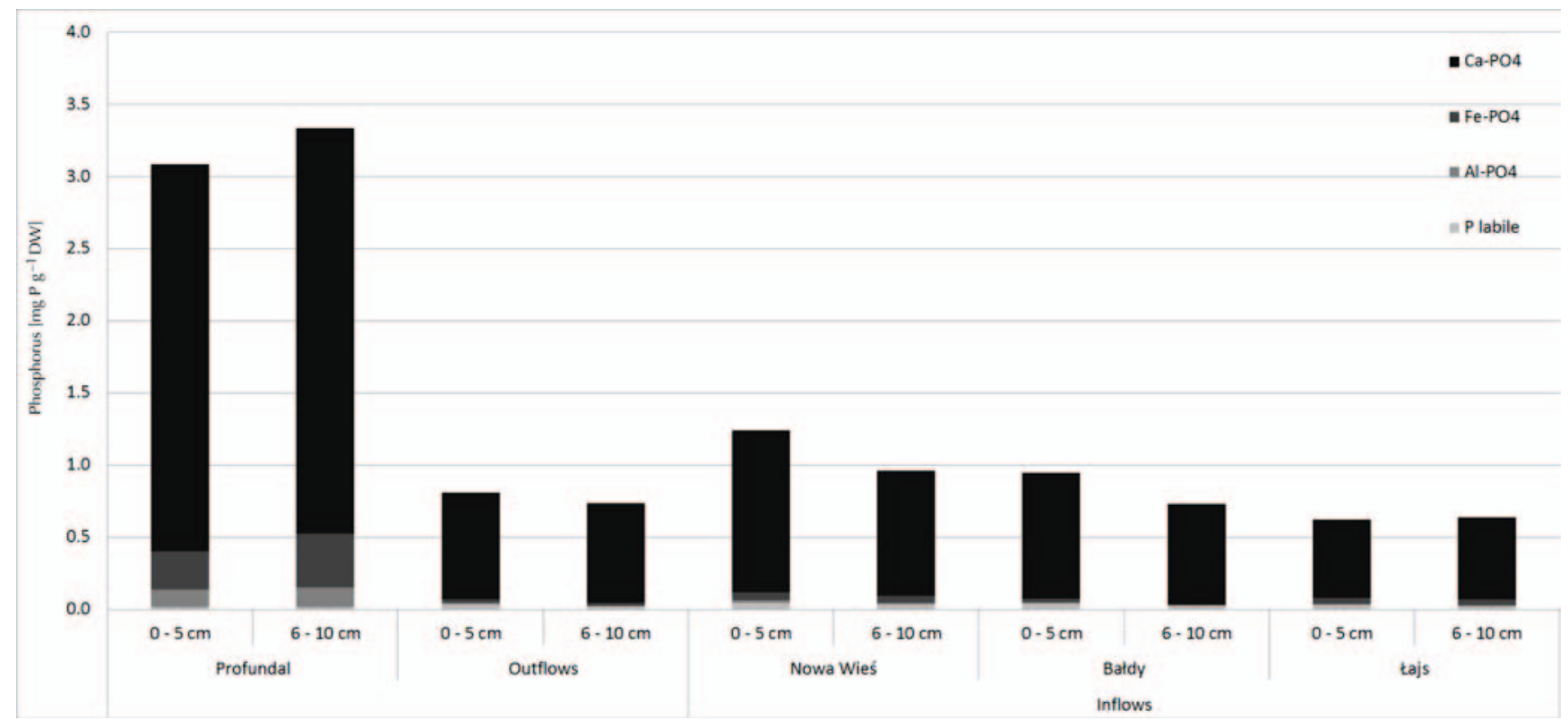

Fig. 11. The spatial distribution of phosphorus fractions 
available. It may be released from anaerobic sediments and becomes an internal $\mathrm{P}$ source for water bodies (Kleeberg and Dudel 1997). The BD-P concentrations in the lake exhibited high variability at all sampling sites. This difference might be related to the concentrations of oxic sediment surface in zones of inflows that act as a boundary layer for upwards diffusing P, Fe and Mn (Gonsiorczyk et al. 1998). The values of BDP in Lake Łajskie are relatively low in comparison to the values reported for other lakes. A low content of reductant $\mathrm{P}$ in sediments has been associated with DO depletion occurring in sediments of hypertrophic lakes during summer, and/or with high $\mathrm{pH}$ values or bacterial activity that might enhance P-release from this fraction (Maine et al. 1992; Ting and Appan 1996; Perkins and Underwood 2001). In addition, high organic content in sediments may inhibit binding of $\mathrm{P}$ by $\mathrm{Fe}$, possibly by competition from binding sites (Kleeberg and Kozerski 1997).

$\mathrm{NaOH}-\mathrm{P}$ represents $\mathrm{P}$ bound to metal oxides, mainly of $\mathrm{Al}$ and $\mathrm{Fe}$ (Kozerski and Kleeberg 1998). $\mathrm{NaOH}$ extractable phosphorus can be used for the estimation of both short-term and long-term available $\mathrm{P}$ in sediments and is a measure of algal available $\mathrm{P}$ (Zhou et al. 2001). This fraction might be released for the growth of phytoplankton when anoxic conditions prevail at the sediment-water interface (Ting and Appan 1996). The relative contribution of $\mathrm{NaOH}-\mathrm{P}$ to sedimentary inorganic $\mathrm{P}$ was rather similar at all sample sites. These Fe and Al-P fraction reports from 27 lakes suggest wide variation in this fraction (5-70\%) with higher values found in eutrophic non-calcareous environments (Penn et al. 1995).

$\mathrm{HCl}-\mathrm{P}$ represents $\mathrm{P}$ forms sensitive to low $\mathrm{pH}$, assumed to consist mainly of apatite $\mathrm{P}$, which is natural and detrital, $\mathrm{P}$ bound to carbonates and traces of hydrolysable organic P. Calcium bound $\mathrm{P}$ is a relatively stable fraction of sedimentary $\mathrm{P}$ and contributes to a permanent burial of $\mathrm{P}$ in sediments (Gonsiorczyk et al. 1998; Kozerski and Kleeberg 1998). The high HCl-P could be attributed to the calcareous terrain of the recharge area. High portions of calcium mineral-P were also observed in lakes having varying trophic status. In these lakes $\mathrm{Ca}-\mathrm{P}$ and residual-P fractions were dominant, together comprising $35-90 \%$ of the TP, with calcareous sediments close to the upper end of the range (Penn et al. 1995).

In riverine-lacustrine systems the low potential binding capacity of phosphorus by sediments and the high degree of internal release into the whole reservoir are unfavourable for the protection of water quality of the reservoir located below. As Vannote et al. (1980) and Minshall et al. (1985) show, transport and transformation of mineral substances depend on the type of chemicals and the location of the lake in the river system; the lake is affected by the transport of ions across the river. Ions transported to lakes can form sparingly soluble compounds (e.g. calcium) or those whose solubility depends on the redox potential (e.g. in combination with iron). These compounds sink in the sediments of the lake, or are released from them in changing physical-chemical conditions. Transport of nutrients in water is very complex. Nutrients which enter the riverine-lacustrine system are quickly turned into the circulation of matter. Especially in the case of phosphorus which binds easily or is poorly soluble (Bajkiewicz- Grabowska and Zdanowski 2006).

\section{Conclusion}

Lakes play a dominant role in the transformation of the circulation of biogenic substances in riverine-lacustrine systems. The greatest content of phosphorus, especially in the bioavailable fractions, was found in the surface layer of $0-5 \mathrm{~cm}$. With increasing depth of the sediment, the content of the bioavailable fractions of phosphorus decreased.

Higher content of phosphorus was found in the sediments from the inflows, to which untreated domestic sewage had been discharged for a few years in the past. In the pool of phosphorus accumulated in the surface layer, ca. $65 \%$ occurred in biologically available fractions. This relatively high value of phosphorus supported intensive algal bloom during the vegetation season, which resulted in the deoxygenation of the water below the water surface layer and resumption of internal loading. The load of nutrients flowing from Lake tajskie may contribute in the future to the degradation of Lake Kośno.

\section{References}

[APHA] American Public Health Association, 1985, Standard Methods for the examination of water and wastewater, Amm. Publ. Health Ass. Inc., New York, p. 1268.

Bajkiewicz-Grabowska E., Zdanowski B., 2006, Phosphorus retention in lake sections of Struga Siedmiu Jezior, Limnol. Rev. 6: 5-12.

Brzozowska R., 2003, Wpływ wieloletniego sztucznego napowietrzania na przykładzie jeziora Długiego na wymianę związków biogennych między osadami a wodą 
(Effect of long-term artificial aeration on the exchange of biogenic compounds between settlements and water based on the example of Lake Długie) [Dissertation], Wydz. Ochrony Środowiska i Rybactwa UWM w Olsztynie, Olsztyn.

Brzozowska R., Kang K.H., 2010, Powierzchniowa warstwa profundalowych osadów dennych jezior Kuc, Majcz Wielki i Mikołajskiego (Surface layer of the profundal bottom sediments of Lakes Kuc, Majcz Wielki and Mikołajki), [in:] Dunalska J. (ed.), Warunki środowiskowe i stan troficzny jezior Kuc, Majcz Wielki i Mikołajskiego. Pojezierze Mazurskie (Environmental conditions and the trophic state of Lakes Kuc, Majcz Wielki and Mikołajki. Masurian Lakeland), Wyd. UWM, Olsztyn: 89-101 (in Polish, English summary).

Chang S.C., Jackson M.L., 1957, Fractionation of soil phosphorus, Soil Sci. 84: 133-144.

Golachowska J., 1977a, Prosta i szybka metoda oznaczania fosforu w osadach dennych jezior (A simple and rapid method for determining total phosphorus in bottom sediments of lakes), Rocz. Nauk. Rol. H. 98: 27-37 (in Polish, English summary).

Golachowska J., 1977b, Oznaczanie całkowitej zawartości fosforu mineralnego i organicznego w osadach dennych jezior (Determining total mineral and organic phosphorus content in bottom sediments of lakes), Rocz. Nauk. Rol. H 98(2): 39-49 (in Polish, English summary).

Golachowska J., 1977c, Frakcjonowanie i oznaczanie mineralnych postaci fosforu w osadach dennych jezior (Fractionating and determining mineral forms of phosphorus in bottom sediments of lakes), Rocz. Nauk. Rol. H 98: 51-63 (in Polish, English summary).

Gonsiorczyk T., Casper P., Koschel R., 1998, Phosphorus binding forms in the sediment of an oligotrophic and an eutrophic hardwater lake of the Baltic district (Germany), Water Sci. Technol. 37(3): 51-58.

Hermanowicz W., Dojlido J., Dożańska W., Koziorowski B., Zerbe J., 1999, Fizyczno-chemiczne badanie wody i ścieków (Physico-chemical investigation of water and sludge), Arkady, Warszawa, p. 627 (in Polish)House W.A., Denison F.H., 2000, Factors influencing the measurement of equilibrium phosphate concentrations in river sediments. Water Res. 34(4) 1187-1200.

Kaiserli A., Voutsa D., Samara C., 2002, Phosphorus fractionation in lake sediments - Lakes Volvi and Koronia, N. Greece, Chemosphere 46: 1147-1155.

Kalff J., 2002, Limnology, Prentice Hall Ltd., Upper Saddle River, p. 592.

Kentzer A., 2001, Fosfor i jego biologicznie dostępne frakcje w osadach jezior o różnej trofii (Phosphorus and its biologically accessible fractions in bottom sediments of lakes of diverse trophic state), Wyd. UMK, Toruń, p.111 (in Polish).

Kleeberg A., Dudel G.E., 1997, Changes in extent of phosphorus release in a shallow lake (Lake Grosser Muggelsee; Germany, Berlin) due to climatic factors and load, Mar. Geol. 139: 61-75.
Kleeberg A., Kozerski H.P., 1997, Phosphorus release in Lake Grosser Muggelsee and its implications for lake restoration, Hydrobiologia 342/343: 9-26.

Kozerski H.P., Kleeberg A., 1998, The sediments and the benthic pelagic exchange in the shallow lake Muggelsee, Int. Rev. Hydrobiol. 83: 77-112.

Maine M.A., Hammerly J.A., Leguizamon M.S., Pizarro M.J., 1992, Influence of the $\mathrm{pH}$ and redox potential on phosphate activity in the Parana Medio system, Hydrobiologia 228: 83-90.

Minshall G.W., Cummius K.W., Petersen R.C., Cushing C.E., Bruns D.A., Sedell J.R., Vannote R.L., 1985, Developments in stream ecosystem theory, Can. J. Fish. Aquat. Sci. 42: 1045-1055.

Murphy T.P., Lawson A., Kumagai M., Babin J., 1999, Review of emerging issues in sediment treatment, Aquat. Ecosyst. Health 2: 419-434.

Penn M.R., Auer M.T., Van Orman E.L., Korienek J.J., 1995, Phosphorus diagenesis in lake sediments: investigation using fractionation techniques, Mar. Freshwater Res. 46: 89-99.

Perkins R.G., Underwood G.J.C., 2001, The potential for phosphorus release across the sediment-water interface in an eutrophic reservoir dosed with ferric sulphate, Water Res. 35(6): 1399-1406.

Pettersson K., 2001, Phosphorus characteristics of settling and suspended particles in Lake Erken, Sci. Total Environ. 266: 79-86.

Psenner R., 1988, Fractionation of phosphorus in suspended matter and sediment, Ergeb. Limnol. 30: 98-113.

Psenner R., Pucska R., Sager M., 1984, Die fractionierung organischer und anorganischer phosphorverbindungen von sedimenten versuch einer Definition okologisch wichtiger tractionen, Arch. Hydrobiol. (Suppl. 10): 115-155.

Ramm K., Scheps V., 1997, Phosphorus balance of a polytrophic shallow lake with consideration of phosphorus release, Hydrobiologia 342/343: 43-53.

Rydin E., 2000, Potentially mobile phosphorus in Lake Erken sediment, Water Res. 34(7): 2037-2042.

Søndergaard M., Windolf J., E. Jeppesen, 2001, Retention and internal loadings of phosphorus in shallow, eutrophic lakes, The Scientific World J.1: 427-442.

Søndergaard M., Windolf J., Jeppesen E., 2003, Role of sediment and internal loading of phosphorus in shallow lakes, Hydrobiologia 506-509: 135-145.

Thirunavukkarasu O.S., Viraraghavan T., Selvapathy P., 2000, A comparative account of phosphorus release from sediments of a lake and a reservoir: laboratory experiments, Fresenius Environ. Bull. 9: 461-467.

Ting D.S., Appan A., 1996, General characteristics and fractions of phosphorus in aquatic sediments of two tropical reservoirs, Water Sci. Technol. 34: 53-59.

Van Hullebusch E., Auvray F., Deluchat V., Chazal P.M., Baudu M., 2003, Phosphorus fractionation and short term mobility in the surface sediment of a polymictic shallow lake treated with a low dose of alum (Courtille Lake, France), Water Air Soli Poll. 146: 75-91. 
Vannote R.L., Minshall G.W., Cummins K.W., Sedel J.R., Cushing C.E., 1980, River continuum concept, Can. J. Fish. Aquat. Sci. 37 (1): 130-137.

Waluga J., Chmielewski H., 1999, Jeziora okolic Olsztyna. Przewodnik Wędkarski (Lakes of the surroundings of Olsztyn. Fishing Guide), Wyd. IRS, Olsztyn: p. 237 (in Polish).

Wetzel R.G., 2001, Lake and River Ecosystems. Limnology, Academic Press, London, p. 1006.

Williams J.D.H., Jaquet J.M., Thomas R.L., 1976, Forms of phosphorus in surficial sediments of Lake Erie, J. Fish. Res. Board Can. 33: 413-429.
[WIOŚ] Wojewódzki Inspektorat Ochrony Środowiska (Voivodship Inspectorate for Environment Protection), 2009, Raport o stanie środowiska województwa warmińsko-mazurskiego w 2008 roku (The Report on the state of the environment of Warmian-Masurian Voivodship in 2008), Biblioteka Monitoringu Środowiska, WIOŚ w Olsztynie, Olsztyn, p. 151 (in Polish).

Zhou Q., Gibson C.E., Zhu Y., 2001, Evaluation of phosphorus bioavailability in sediments of three contrasting lakes in China and the UK, Chemosphere 42: 221-225. 